\title{
Geological Setting and Coastal-marine Ecosystem of Butrinti Region, Albania
}

\section{Telo Velaj*}

Tirana University, Faculty of Geology, Warrington, PA 18976, USA

\begin{abstract}
Butrinti region is the part of the Cika anticlinal belt, which is the most western part of the lonian zone. This region located in the most southern part of Albania, near the Greek border. From the tectonic point of view, it is the part of the Cika anticlinal belt, which is in the western part of the External Albanides. In the western side of this anticlinal belt developed one regional over thrust fault. Through this over thrust Cika anticlinal belt and all the lonian zone over thrust in westward with amplitude around 50-100 km above the Apulian Platform (Sazani zone in Albania) and the South Adriatic basin.
\end{abstract}

The most widespread formation there is: Evaporite (Upper Triassic), carbonate (Upper Triassic-Eocene), flysch (Oligocene-Aquitaniane), molasses (Serravalian-Pliocene) and Quaternary.

Keywords: Albanides; Butrnti; Geology; Marine environment

\section{Introduction}

Butrnti is placed in the most southern part of the Ionian zone and has a geological situation very complicated due to result of development of the evaporitic diapirs and thrust tectonics. From the south (Butrnti) to the north (Vlora City) the number of the lines of the Cika anticlinal belt is decreased (Figure 1). Generally the structures are From the South to the North, the number of structural lines of the Cika belt is decreased (Figure 2). The diapirism tectonics are very intensive, especially in the southeastern part, where it presents the principal character of the geological feature with the evaporite diapirs: Xara in Butrinti region, Filati and Corfu in Greece (Figure 1). This anticlinal belt, generally, has a strike NW with azimuth $330^{\circ}$ (Figure1). In the Butrnti region are developed two Lakes: Butrnti and Bufi Lakes (Figure 2).

Butrinti Lake has a surface about $20 \mathrm{~km}^{2}$. The long is $7 \mathrm{~km}$ and the width about $3 \mathrm{~km}$. The maximal profundity is $21 \mathrm{~m}$. The water of the Butrnti Lake is salted. This Lake communicates with the Ionian Sea through the Vivary channel (Figure 2). In the east of Butrnti lake is the Bufi Lake, which has the sulfide water. This water has the spring from the contact between the evaporite and carbonate. Formations in the border of Xara diapir (Figure 2). Both these lakes have communication between them. The Bufi Lake is have the level about 5-6 $\mathrm{m}$ high from the Butrnti.

\section{On geological setting of the Butrrinti region}

The Cika anticline belt is a more western unit of the Ionian zone. Westwards is the Apulian platform and its transitory part, which have been folded into big structural units which would be very significant oil prospects. In the western side it is limited by a regional thrust fault by which is realized the total westward thrust of External Albanians with amplitude about $50-100 \mathrm{~km}$. over western authochton ( Figure 1). In general the anticline structures of Cika anticlinal belt are large size up to $30 \times 10 \mathrm{~km}$. The evaporitic diapirisim is very intensive, especially in the Southern part, where it presents the principal character of geological feature (the Filati, Xare-Mursi, Corfu etc.) [1]. In the north part and particularly in the structures opposite to Sazani zone (Appulia platform) the backthrust development is the most typical. The duplex model is expected to occur in the South of Vlora area. Until to the south (Butrnti region) of linear type of large size (30-10 km). Backthrust faults of local character, which is developed on the eastern flank of different anticline structures of the Cika anticlinal belt (Saranda anticline etc.) (Figure 2). In the Southern part of the Butrinti region was formed by the Bogaz-Saranda anticline, which in southward as a result of the eruption of the evaporite diapir (Xara diapir) (Figures 1 and 2) near its top, was divided into two parts: On the east the Bogaz carbonate anticline and on the west the monoclinal of the Karafi. The dipping of the east (Figure 2) for location flank is E25-30 and the dipping of the deposition of the Karafi monoclinal is W $15-20^{\circ}$ (Figure 2). In this area the Cika anticlinal belt has a wiidth of about $35 \mathrm{~km}$ (Figure 2).

Northward the Bogaz anticline continues to the Saranda carbonate anticline, the eastern flank of which was complicated by a backthrust (Figure 1). So, this anticline has an east asymmetry in its northern part. More to the north, this anticline is covered by the Ionian Sea (Borsh village). The Xara evaporite diapir is extended in the central part of

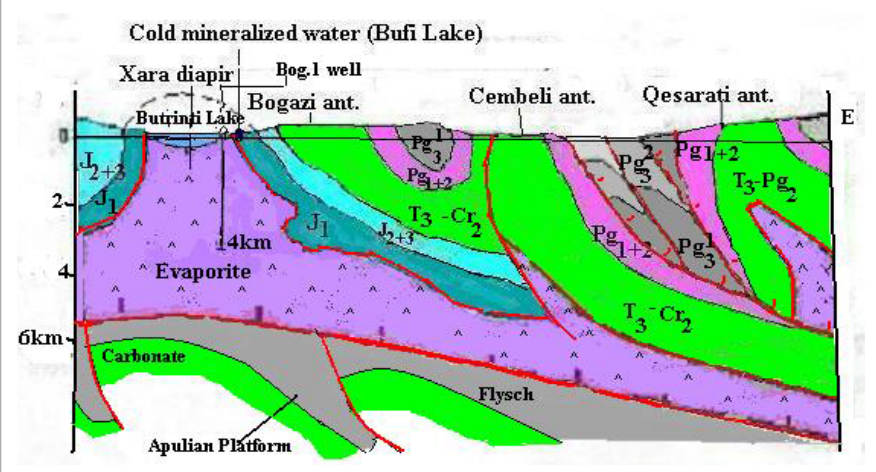

Figure 1: Schematic geological cross-section through Butrinti region.

*Corresponding author: Telo Velaj, Tirana University, Faculty of Geology, 700 Street Road Apt, A-7, Warrington, PA 18976, USA, Tel: +3554400139; E-mail: telovelaj6@gmail.com

Receive July 12, 2015; Accepted October 17, 2015; Published October 27, 2015

Citation: Velaj T (2015) Geological Setting and Coastal-marine Ecosystem of Butrinti Region, Albania. J Pet Environ Biotechnol 6: 252. doi:10.4172/2157-7463.1000252

Copyright: (c) 2015 Velaj T. This is an open-access article distributed under the terms of the Creative Commons Attribution License, which permits unrestricted use, distribution, and reproduction in any medium, provided the original author and source are credited. 
the Bogaz-Saranda carbonate anticline and in the Butrnti Antique Citty. The stratigraphic section consists of Upper Triassic evaporites $\left(\mathrm{T}_{3}\right)$, carbonate from Upper Triassic to Eocene $\left(\mathrm{T}_{3}-\mathrm{Pg}_{2}\right)$, flysch and flyschoides from Oligocene to Aqutianiane $\left(\mathrm{Pg}_{3}^{1}-\mathrm{N}_{1}^{2 \mathrm{~L}}\right)$; which are involved in imbrication and duplex systems (Figures 1 and 3).

The molasses formation represented by Pliocene $\left(\mathrm{N}_{2}^{\mathrm{P}}\right)$, is also present. Their thickness is about $.200 \mathrm{~m}$ and overlies trangresively the old deposits (Figure 3). In the Pliocene deposits have been discovered the important coal reserves with $4000 \mathrm{k} /$ kalorie. We stress that in Butrinti region, besides the powerful Pliocene-Quaternary accumulation, there occurs also the reconstruction of the the structural plane, which has caused strong earthquakes [2] (Figure 3). The Butrinti graben consists of Pliocene-Quaternary sediments The marine sediments of Pliocene ewith the total thic around $200 \mathrm{~m}$, overlie the evaporites of XaraButrnti diapir and outcrop at Xara and Mursi hills (N2). Due to local extensional during the Pliocene, a horst-graben was created at the edge of the Ionian thrust front, where marine Pliocene formed in submerged grabens. This extensional tectonics was still active in Quaternary, when the Butrinti Lake was formed. These local extensions was conditioned by the evaporate terctonics. The presence of the evaporites in the basement



Figure 2: Schematic geological cross-section through Butrinti region.

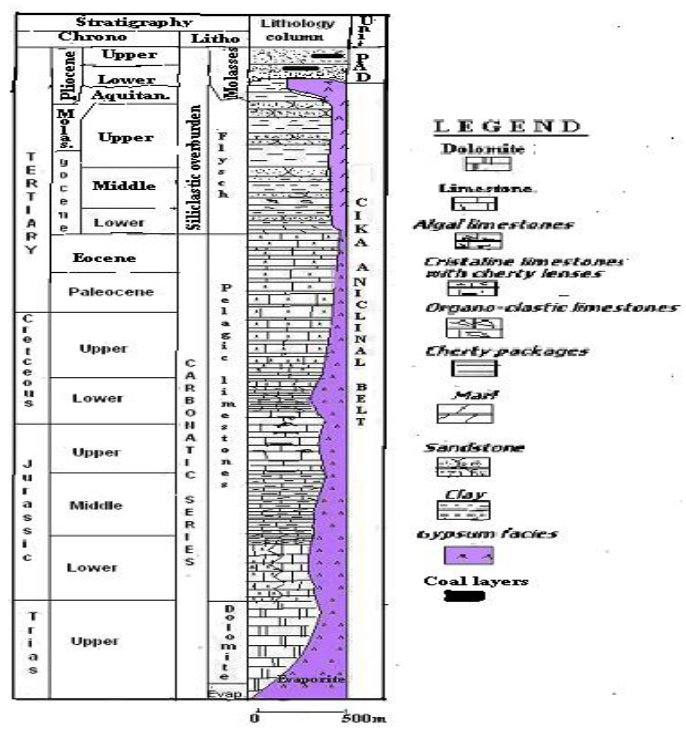

Figure 3: General lithologo-stratigraphic column of the Butrnt region (Produced by Velaj). and their vertical movement that continues, have been the main factor that made the structural and paleogeographycal changes during the Pliocene time. The deposits form of the synclinal of Xara-Mursi has a generally strike NW-SE. Northward this divided by a tectonic fault that represent the tectonic contact between the limestone's on the east and evaporites on the west into two parallel synclinal is moved eastward, by a trancurrent fault, which affected and the carbonate rocks (Figure 2).

The Quaternary sediments outcropping on Vrina plain consist of alluvial and lagoon deposits, up to $80 \mathrm{~m}$ thickness [3].

On the western side, the rugged shore of the Butrnti Antique City, rise steeply from the deep water of the Ionian Sea (Figure 2), while on the eastern side of Butrnti Lake. On the tough it is bordered by the lake to the sea and vice-versa. The channel separates the peninsula from the land beyond, this the city occupies well protected by nature. The hill, on which city arose and developed, is not too big. It is composed of limestone deposits (J1-J2 and J3) and partly by Pliocene deposits, covered with a hard layer of the soil. On the south side a rampart of rocks rises vertically from the flat below, while the other sides, from the most falls away steeply to the edge of the lake. On the west side alone a narrow of land which broader into the flat, links the hill with remainders of the peninsula (Figure 2).

\section{The origin of the Butrnti Lake and its basic characteristics}

From historical evidences and archeological excavation Butrinti City is identified as a city during the VI-VII century BC. The building activity of this City shows that that economical trading and cultural development had suffered two important declines. The first decline is that of IV century and the second that of XII century, which correspond with $358 \mathrm{AC}$ and $1153 \mathrm{AC}$ earthquakes. Concerning the origin of this lake there are two main hypotheses:

Firstly, the Butrnti Lake was a simple bay of the Ionian sea.

Secondly, the formation of this lake was as result of the tectonic phenomena. The tectonic movement caused depression of this area, where today is placed the Butrnti Lake. Butrnti region is presented, in general, one subsidence area in shape of the graben. This region was subjected to the action of the subsidence during the PliocceneQuaternery time. For this event we have the testification the finding below the Quaternary sediments a part of this antique City (amphitheter etc.) by magnetic study, carried out by Albanian specialists. Also, at this time, it is known that a part of remain in Ancient Butrnti City is below the sea level [4].

Butrinti lake has a surface about $20 \mathrm{~km}^{2}$. The long is $7 \mathrm{~km}$ and the width about $3 \mathrm{~km}$. The maximal profundity of the lake is $21 \mathrm{~m}$. This lake is found in Quaternary time, while the Ionian sea is founded in the beginning of the Pliocene time. The water of the Butrinti lake is salted. In this lake is developed the fichery. In the east of Butrinti Lake is the Bufi Lake, which has the sulfide cold waters. This water has the spring from the contact between the thrust tectonic of the the Bogazi anticlinal limestone's $\left(J^{1+2+3}\right)$ with the evaporite diapir of the XaraButrint (Figures 1 and 2). Cold mineralized waters forming the Bufi Lake are three powerful sources with significant debt (over $360 \mathrm{~m}^{3 /} / \mathrm{h}$ )) this water represent chloro-sodium type and have temperature $12^{\circ} \mathrm{C}$. Bufi Lake has the level about 5-6 m higher then Butrnti Lake, which shows that it is possible to communicate between them. As previously mentioned the hill of the Butrinti City is separated from the plain of Xara-Mursi by the Vivary channel. Its evolution was favored by the presence of a series of faults, with NE-SW and N-S direction. These faults have played an important role in the shape of the topography 
and in the creating of the Lake. In the southern part of the XaraMursi plain, in the contact with Karafi monoclinal, is the river of the Pavllo. This river goes in the Ionian Sea forming delta that extends northeast and eastwards. Actually the deltaic activity is creating new small bays and lakes of type Butrinti. From the Greek border to Vlora City in the north, morphologically building the Ionian coast the Cika anticlinal belt represent a height zone with the carbonate structures well development that outcrop until the level of Upper Tiaiassic (Figure 2) Carbonate and sandy beaches, lagoons, fiords etc. compose a special, precious nature and tourist resource [5].

Thanks to its geographical location in the Mediterranean area, its geology and climate, Albania has the major advantage in comparison with another country for development of tourism. The shore of the Ionian Sea is charcterized by the remarkable variety both in morphology and in biological species. We stress that the shores of the Ionian Sea is characterized by the remarkable variety both in morphology and in biological species. The Butrnti Lake is placed in a seaside in the southwestern of Albania, famous for its archeological monuments (ancient part of Buthrotum), historical significance, and natural richness. The core areas are composed by a tectonic lagoon that is surrounded by forested hills and mountains and complemented by saltwater and freshwater marshlands. From the geomorphological point of view, the Butrti Lake is contained in the Ionian Sea.

The Catchment of the Butrnti Lake is defined by the Bistrica River in the north, Ksamili mountains in the West and the Pavlo River in the south. The Lake has a tectonic origin, while the water regime is typical of coastal lagoons. It joins with the Ionian Sea through the channel of Vivary (3600 m long, 60-100 m wide and 5-6 m deep). During the high tides (approx. 15-20 cm), the Sea level rises and as consequence the saline water penetrate into Lake of Butrnti. The opposite phenomenon happens during the low tides. A small amount of continental water, deriving from the Bistrica and Kalasa rives, enters the lagoon in its northern side. The Butrrnti Lake has mesotrophic water with eutophric tendencies in certain risky areas. The limnology of the lake is divided into two distinct layers. The upper layer (approx. $8 \mathrm{~m}$ in depth) is rich in oxygen. Its concentration is about $8-9 \mathrm{mgr}$./lit on the surface and reduces to zero by the depth of 7, 5-8 m. Information sheet on Salinity fluctuates with the seasons: from $15.00 \mathrm{gr} / \mathrm{lit}$ in winter till 33.0 $\mathrm{gr} /$ lit in summer. The value of $\mathrm{pH}$ oscillates. Ramsar wetlands (Ris): Butrnti 4 between 6.5 and 9.5. The organic matter is about $2-10 \mathrm{mg} /$ lit. Water temperature fluctuates $14^{\circ} \mathrm{C}$ in winter till $25^{\circ} \mathrm{C}$ in summer. The low layer is rich on sulfuric gas. Its concentration increases with depth and reaches the highest level at the bottom of the lake $(>5.0$ $\mathrm{mgr} / \mathrm{lit})$. Salinity remains nearly the same throughout the year $(35.00$ $\mathrm{gr} /$ lit) Temperature has a relative homothermy of $10^{\circ} \mathrm{C}$ throughout the whole year. No animal are found in the lower layer. The Butrnti Lake is surrounded by different higher ranges of mountains and hills (Figure 2). The higher terrain compliment the lower weet land areas by providing environmental corridors and areas where there is less human disturbance of wildlife. The coastline is much refracted, with many peninsulas, islands and small deep bays. From the morphological point of view it is divided into two main types: high abrasive coast and low accumulating coast. The Butrnti region is characterized by the mild Mediterranean climate. The annual average temperature is $17.1^{\circ} \mathrm{C}$. Temperatures fluctuate from $9.7^{\circ} \mathrm{C}$ in January to $25.1^{\circ} \mathrm{C}$ in August. Rain precipitations relatively high, over $1,500 \mathrm{~mm}$ per year Very close to Butrnti Lake is placed a historical area Butrnt. Butrint occupies the small Ksamili peninsula between the strait of Corfu and Butrnti Lake (Figure 2).

\section{The Butrnti ancient city and its archeological values}

The city of Butrnti (Bothrota) is one of the fragments which form the fabric of Albania's ancient cultural landscape. Nestlingin the highlands in the far south of the country and surrounded by dense vegetation, Butrnti was doubly protected by nature and by the fortifications which its habitants built in ancient times. However, this was not sufficient to isolate the city from the rest of the world (Figure 4). Less than $10 \mathrm{~km}$ from the island of Corfu, Butrnti was linked to the Mediterranean by the Vivari chanal,, which ran from the Butrnti Lake The proximity of the two Ionian Sea and the lake, the gentle climate and the beauty of the sourrounds country-side provided a splendid environment for the foundation of the city. In taking advantage of this site, the archi-tects of the past constructed what was to become one of the major maritime and commercial of the Ancient World. Butrnti reached the height of the glory in the $4^{\text {th }}$ century B.C., at which time the numbered 10,000 Inhabitants [6].

The sight of fortifications alone, which date from the $6^{\text {th }}$ century B.C., evokes the military and economic potential of the city at this time. The hill on which the Acropolis stands is encircled by a wall built of huge stone blocks. In places this wall is two meters high and 3.5 meters wide. The amphitheater, dating from the 3 rd century B.C., bears witness to the cultural riches of the city. The stone banks of the seating of wich twenty three rows have been preserved would have held an audience of 1500 (Figure 4). The theater is situated at the foot of the Acropolis, close by two temples, one of which is dedicated to the Acleplos, the Greek god of medicine, who was worshiped by the city's inhabitants. Approximately thirty inscriptions, almost all in ancient Greek, carved the western facade of this temple, and another hundreds of so found in a tower which was rebuilt in the $1^{\text {st }}$ century B.C., are the only examples of writing discovered in Butrnti. Excavations have brought to light many objects as plates, vases, ceramic candlesticks as well as sculptures, including a remarkable "Goddes of Butrinti", which seems to be completely embodying, in the perfection of its features, the Greek ideal of physical beauty. Christianity brought new life to Butrnti. The palaeo-Chritian period adorned the city with two basilicas and baptistery, which is among the most beautiful in the Mediterranean region. Sixteen granite columns, forming two concentric circles, support the roof of the main hall. The floor is paved with a magnificent mosaic representing the Tree of Life and decorated with medallions embellished with animal motifs. Barbarian incursions and Normand raids in the eleventh century, a catastrophic earthquake in 1153, and conquest by the Venetiansin1386, the subterranean infiltration from of water and subsequence epidemics completed the ruin of the city

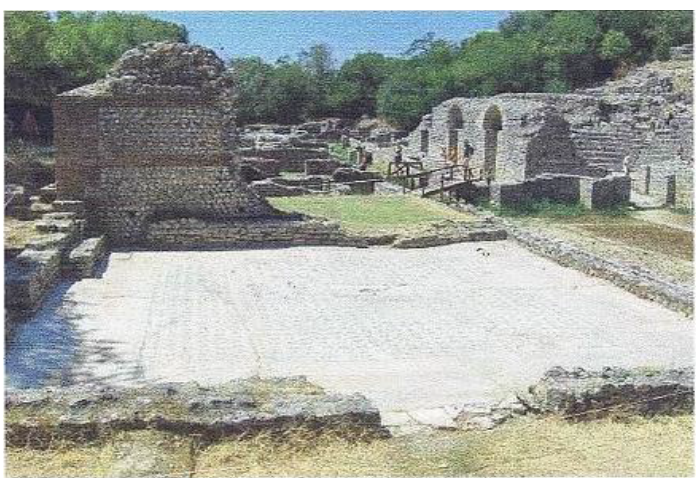

Figure 4: The view of the Ancient City of Butrint. 
and forced the inhabitants to flee. Butrinti was buried in silence and oblivion. Throughout the occupation by the Ottoman Empire, from the $15^{\text {th }}$ to the $20^{\text {th }}$ centuries, the City remains in deep slumber. The theaters covered Butrnti in mud, and abundant vegetation completely hid the remaining from the view.

It was not until the beginning off the $20^{\text {th }}$ century that systematic excavations were carried out at the Butrnti by the Italian archeologist I. Ugolini, followed by his compatriots P. Marconi and D. Mustili. Between 1926 and 1941, the ground was cleared and the ancient city began to reveal its hidden treasures. After 1944, Albanian archeologists undertook more ambitious excavations. In turn, the ramparts, the acropolis, the agora, the amphithater, the temples, the public baths and private residences reemerged into the light of day. The entire city arose, almost intact, under fascinated gaze of the archeologists. Today, this rediscovered city represents a unique cultural treasure whose value far surpasses national frontier.

\section{Conclusion}

Butrnti represents a very complicated area from the geological point of view. This kind of development dedicated from orogenitic activity aided by the effect of the evaporite tectonics. In this region are developing some tectonics units:

1. Cembel anticlinal line, which continues from the Greece, while in Albanian territory it melts in Vurgu syncline (Figure 2).

2. Bogaz-Butrnt-Sarande anticlinal line, which constitutes from several structures:

a) Bogazi anticline, which expanded greatly, due to the effect of the eruption of the Xara evaporite diapir, eruption that occurred in its central part (Figure 2). Width of this anticline in this sector reaches 35 $\mathrm{km}$., while the length is around $30 \mathrm{~km}$.

b) Saranda anticline is a continuation of that of Bogaz. This anticline has considerable size $(18 \times 6 \mathrm{~km})$ in its eastern flank, near the northern periclinal, develpoped one backthrust fault, which causes an overthrust in eastward, over the Nivica synclinal (Figure 2).

3. Xara evaporite diapir, spread across the southern border with the Greece and continues throughout the Vrina plain until to northern part of the Butrinti Lake, where is overlie by Pliocene trasgressive deposits. In this situation this diapir has a length more than $20 \mathrm{~km}$., while the width is around $4-5 \mathrm{~km}$. The movement of this diapir has conditioned the formation of the depression of the Butrint area, stimulaying features of widening tectonic in this region and in all the external Albanides. The character of widening tectonic is expressed during the PlioceneQuternary and continued up today.

4. Butrinti has outstanding historical value as archeological centre, these values surpasses national frontiere. The importance of the Butrinti can be gauged from its inclusion in 1992 on UNESCO's World heritage list.

5. The tectonics movements caused the subsidence of this area, during Pliocene-Auaternary time. In this area with the shape of graben placed the Butrint Lake, which was formed in the Quaternary period.

\section{References}

1. Velaj T (2011) Tectonic Style in Western Thrustbelt and its Implicationon Hydrocarbon Exploration. Search and Discover Milano, Italy.

2. Aliaj SH (2012) Neotectonic of Albania, Monography, Tirana, Albania.

3. Moisiu L, Durmishi C (2015) Sedimentological study of the Quaternary deposits of Saranda area, Albania. Online International Interdisciplinary Research Journal 5: 30-41

4. Kavaja V, Durmishi S, Vincani $F(2012)$ The evaluation impact of the geological environment in expansion of ancient civilazitation of the Butrinti-Foenika region, southern Albania, Fall meeting, 2003

5. Vilas N (2004) Etude d'analogues de reservoirs dans les chaines plisses et leurs avant pays: Sedimentologie, diagenese, deformation et fracturation des systemes carbonate Cretaces superiieur-Eocenesdu Bassin Ionian (Albanie meridionale). Geoscinces et Resources Naturelles, Paris.

6. Jarret A, Lobell (2006) Ages of Albania. A publication of the Archeological Institute of America 59. 